\title{
Decline of the Commercially Attractive White Morph in Goliath Beetle Polymorphic Populations
}

\author{
Daniele Dendi ${ }^{1,2,3}$, Stephanie N. Ajong ${ }^{4}$, Giovanni Amori ${ }^{5}$ and Luca Luiselli ${ }^{1,2,3, *(D)}$ \\ 1 Institute for Development, Ecology, Conservation and Cooperation, 00144 Rome, Italy; d.dendi@ideccngo.org \\ 2 Department of Applied and Environmental Biology, Rivers State University of Science and Technology, \\ Port Harcourt P.M.B. 5080, Nigeria \\ 3 Department of Zoology, University of Lomé, Lomé 01 BP 1515, Togo \\ 4 Department of Fisheries, Lagos State University, Lagos Ojo 102101, Nigeria; ajong.stephanie@gmail.com \\ 5 National Research Council (CNR), Institute of Research on Terrestrial Ecosystems, 00185 Rome, Italy; \\ giovanni.amori@cnr.it \\ * Correspondence: 1.luiselli@ideccngo.org
}

Citation: Dendi, D.; Ajong, S.N.; Amori, G.; Luiselli, L. Decline of the Commercially Attractive White Morph in Goliath Beetle Polymorphic Populations. Diversity 2021, 13, 388. https://doi.org/10.3390/d13080388

Academic Editor: Roberto Pizzolotto

Received: 8 August 2021

Accepted: 15 August 2021

Published: 18 August 2021

Publisher's Note: MDPI stays neutral with regard to jurisdictional claims in published maps and institutional affiliations.

Copyright: (c) 2021 by the authors. Licensee MDPI, Basel, Switzerland. This article is an open access article distributed under the terms and conditions of the Creative Commons Attribution (CC BY) license (https:// creativecommons.org/licenses/by/ $4.0 /)$.

\begin{abstract}
The Goliath beetle (Goliathus goliatus) is one of the largest and most commercially valuable (for collection exports) beetle species worldwide, and occurs in West and Central Africa, with polymorphic populations being found in Benin, Eastern Nigeria, and Western Cameroun. The white morph is the most commercially valuable, and therefore is actively searched for by hunters and dealers. In a long-term, opportunistically conducted study in south-eastern Nigeria, we documented a substantial decline of the white morph compared to the normally coloured brown morph, although an overall decline in the number of observed beetles was evident for both colour morphs. Although a combination of reasons may have caused the white form decline, it is likely that overcollecting was the primary threat behind the observed pattern. Therefore, we urge the competent authorities to better protect the polymorphic populations of these giant beetles and the International Union for the Conservation of Nature (IUCN) to make a quick assessment for eventual inclusion of the species among the threatened taxa Red List.
\end{abstract}

Keywords: Goliathus; polymorphism; over-hunting; Africa; Nigeria

\section{Introduction}

Many beetle species are especially valued for collections throughout the world, with large-sized, colourful, and morphologically attractive species being particularly valued [1]. The Goliath beetle (Goliathus goliatus) is one of the largest (up to 100-110 mm long) [2] and most commercially valuable (for collection exports) beetle species worldwide [3,4] Goliathus goliatus occurs in West and Central Africa, and polymorphic populations occur in Benin, Eastern Nigeria, and Western Cameroun [3-5], with most of the individuals being "normally" coloured (with brown elytra) and a few individuals having white elytra (Figure 1). In these areas, the frequency of occurrence of the white morph (named "quadrimaculatus") is unknown. However, it is well known that the white morph is much more valued by international beetle collectors, and white morph specimens are sold for much higher prices for the same size range than brown morph specimens (for instance on eBay or in Facebook; Amori et al., personal observations). Therefore, the white morph is especially hunted for by local persons (Luiselli et al., original interview data with local collectors). During long-term opportunistic surveys carried out in South-Eastern Nigeria, we collected data on the frequency of occurrence of the various colour morphs of this giant beetle throughout the years, and we evaluated whether the frequency of these morphs was stable or tended to vary across the years. Because of the long-term duration of the field study, the data given here may be instrumental for assessing whether the local harvesting of these beetles is sustainable or not, with special reference to the "quadrimaculatus" morph. 
a)

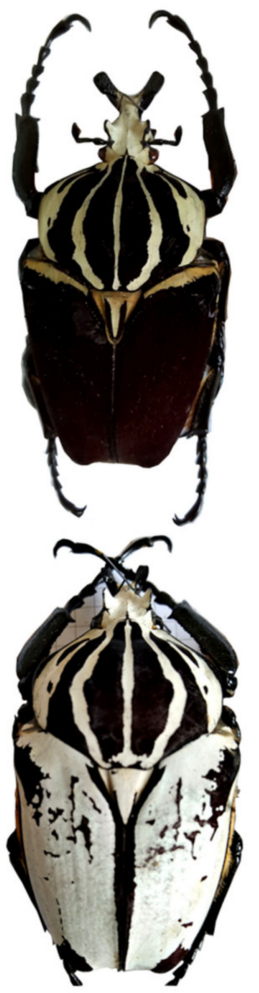

b)

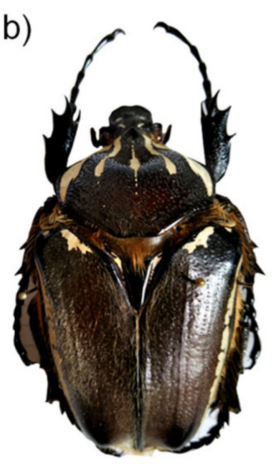

d)

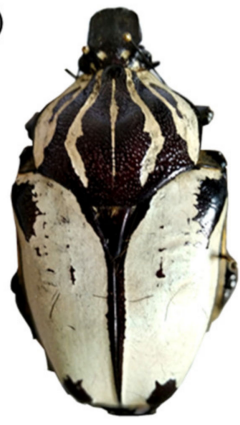

Figure 1. The two sympatric morphs of the Goliath beetle: (a) brown male; (b) brown female; (c) "quadrimaculatus" male; (d) "quadrimaculatus" female. These four specimens are currently deposited in the Private Entomological Collection "Luiselli" in Rome, Italy. Photos: L. Luiselli.

\section{Materials and Methods}

The field study was carried out in the northern Cross River State, South-Eastern Nigeria (precise locality not given for conservation reasons). The study area was characterized by an evergreen hilly/mountainous forest (situated at 500-1000 $\mathrm{m}$ a.s.l.), nearby the border between Nigeria and Cameroun. The climate was typically tropical, with the wet season from April to September and the dry season from October to March. With over $3000 \mathrm{~mm}$ of annual rainfall, this area is one of the wettest zones in West Africa.

Field work was carried out, at irregular time intervals, during 1996-2021, alongside long-term field research on other organisms, mainly reptiles. The total number of field days specifically allocated for surveying beetles was 189 . We ensured a similar sampling effort each month of the year, with sampling undertaken during the same time of the day in the forest habitats. We sampled beetles 14-17 days in each month throughout the study period. During each field day, the study area was randomly searched from 06:00 to 24:00, trying to spend as much time as possible searching for beetles, with similar amounts of time spent in each habitat type. Similar to methods used for monitoring other forest beetle species [6,7], we recorded all adult G. goliatus individuals observed along dirt tracks and paths in forested areas (visual encounter surveys, VES). We used an LED headlamp at night. In each study site, transects were walked concurrently by three persons moving independently of each other. We also recorded individuals that were found dead on the ground, or that arrived attracted by light at night, during field days that were not specifically devoted to beetle sampling.

In the study area, some Goliath beetle colour morphs were observed: the typical brownelytra morph (Figure 1a,b), the "quadrimaculatus" morph with white elytra showing four symmetric black dots at the extremities (Figure 1c,d), and intermediate morphs between these two. These intermediate morphs are characterized by the alternance of brown and white colours on the elytra, with geometric patterns that may be complicated, and that assume the commercially used name of "albatus", "conspersus", "hieroglyphicus", 
"apicalis", and "undulatus" (although these names have no scientific value). Herein, we considered as "white" those individuals where at least $50 \%$ of the elytra were white. However, in our examined sample, there were no cases that could be considered contentious in terms of being assigned to one of the two colour categories (brown or white), as all of the white individuals had elytra that were $>70 \%$ white, and all brown individuals had $>85 \%$ brown elytra (our unpublished data).

\section{Results}

Overall, we observed a total of 248 Goliath beetles (133 males and 115 females), out of which $32(14 \%)$ were white and the remaining $86 \%$ were brown or dark-coloured. Females were more frequently white than males, accounting for $15.6 \%$ versus $10.6 \%$ of the total individuals. The frequency of occurrence of both the white and the brown coloured individuals, as well as the various "commercial morphs" within the observed samples, is presented in Table 1. In terms of "commercial forms", normally coloured and "apicalis" individuals were the most frequently encountered in both males and females (Table 1).

Table 1. Distribution of the recorded Goliathus goliatus individuals by colour morph (white or brown) and by commercial name at the study area in South-Eastern Nigeria.

\begin{tabular}{|c|c|c|c|c|c|c|}
\hline & Brown Males & White Males & TOTAL Males & $\begin{array}{c}\text { Brown } \\
\text { Females }\end{array}$ & White Females & $\begin{array}{c}\text { TOTAL } \\
\text { Females }\end{array}$ \\
\hline Sample size & & & 133 & & & 115 \\
\hline "normal" morph & 64 & 0 & 64 & 66 & 0 & 66 \\
\hline quadrimaculatus & 0 & 7 & 7 & 0 & 11 & 11 \\
\hline apicalis & 38 & 0 & 38 & 31 & 0 & 31 \\
\hline undulatus & 0 & 3 & 3 & 0 & 2 & 2 \\
\hline albatus & 8 & 4 & 12 & 0 & 5 & 5 \\
\hline hieroglyphicus & 2 & 0 & 2 & 0 & 0 & 0 \\
\hline conspersus & 7 & 0 & 7 & 0 & 0 & 0 \\
\hline TOTAL & 118 & 14 & 133 & 97 & 18 & 115 \\
\hline
\end{tabular}

Stratifying the data by three time periods (1996-2004 (66 field days), 2005-2013 (62 field days), and 2014-2021 (61 field days)), it appeared that the white morph has declined dramatically in the percentage of observed individuals: white individuals represented $17.7 \%$ of the total sample in the first time period, $10.9 \%$ in the second time period, and $6.4 \%$ in the third time period. Moreover, the total number of individuals also declined from 113 (in 1996-2004) down to 73 (2005-2013) and 62 (2014-2021).

\section{Discussion}

Our study revealed a clear decline in the observed Goliath beetles throughout the study period, with an even disproportionally heavier decline in the white morph. Although preliminary, and so far only descriptive (not experimental), we attribute this trend to a true population decline of the study species, albeit more experimental approaches would be needed to better define the extent of the decline given that shifts towards an enhanced elusiveness cannot be ruled out. This decline, and in particular the differentially enhanced decline of the white morph, was probably due to overharvesting by local communities. In this regard, although Nigeria is officially unusual as an export area for these animals (compared with Cameroon, for instance; see [3,4]), many individuals are still exported illegally to Cameroon and from there sent to the European and American markets (information gathered from our interviews with local collectors). It cannot be excluded that several individuals that reach the Western world labeled as coming from Cameroon were in fact collected from South-Eastern Nigeria, although the trade is quite hidden, like that of other animal species such as tortoises for instance (our unpublished observations). Moreover, males are harvested preferentially because of their size, colour, and head morphology, and this may cause sex ratio perturbations to the wild populations. Indeed, a declining number 
of individuals has also been observed throughout the years for the other colour morphs of the Goliath beetle (although not as strong a decline as in the "quadrimaculatus" morph).

However, additional reasons may explain the observed pattern, and the biological significance of elytra colouration as revealed in other species of beetles should be considered [8-11]. Intraspecific variability of the elytra colour in beetles can be associated with (i) the trophic pressure of predators (for example, birds or mammals may be more likely to prey upon some colour morphs) [12], (ii) the better reflective ability of white colouration in hot climates (prevention of excessive body heating in individuals with larger body sizes and, accordingly, slower heat transfer to the surrounding space) [13] and the better wettability [14], (iii) different humidity levels at the local population scale [15,16], (iv) the domination of different colour morphs of beetles in different types of plant communities or landscapes [17], (v) a different set of food for the larvae, as a result of which different digestive enzymes are expressed, some of which can be linked to the genes for wing colouring [17], or (vi) direct mechanical collection of beetles with white elytra (as we pointed out at above). The anthropogenic impact on beetles can be both direct (mechanical extermination of a given morphological form) and indirect (for example, through changes in the fauna of parasites of larvae, pupae, or adults, destruction of any food plants, pollution of the environment by insecticides, fungicides, herbicides, heavy metals, or persistent organic pollutants) $[9,11]$. Concerning the white morphs of Goliathus goliatus, it has already been reported that they are declining in some Cameroon sites where they are exploited for international trade [3,4], but the data confirming this declining trend were not given in the original sources. Thus, our study is the first to quantitatively document the decline trend of the white morph in Goliath beetles. Even more worryingly, we documented a substantial decline in a beetle population still under likely less human pressure than other conspecific populations, such as those in Western Cameroon that feed a great part of the worldwide Goliathus trade. Therefore, we anticipate that the decline of the polymorphic G. goliatus populations in Cameroon may be even worst than that of the population studied herein. It is also possible that the genes for resistance to some pesticide(s), which have become widely used in Africa in the last 10-20 years, are linked to genes that determine the coloration (i.e., the degree of coverage with white scales). This latter hypothesis is, however, unlikely in our study case, given that the landscape at the study area is quite well preserved, being situated nearby protected areas (Cross River National Park) with well-preserved mountain evergreen forests where the human impact is low (apart from poaching or the illegal extraction of timber and non-timber products), with no apparent use of chemical pollutants. Furthermore, the change in the occurrence of different colour forms of beetles could be explained by the combined simultaneous influence of two or three of the above-listed factors.

In conclusion, we urge (i) researchers to continue to conduct field studies on the status of the various colour morphs of Goliath beetles in other areas where polymorphism naturally occurs, and (ii) the competent authorities to better protect the polymorphic populations of these giant beetles that, despite still not listed in the IUCN (2021) Red List [18], clearly deserve a quick assessment for eventual inclusion among the threatened taxa.

Author Contributions: Conceptualization: L.L. and G.A., methodology: L.L. and D.D.; formal analysis: L.L.; investigation: S.N.A., L.L. and D.D.; resources: G.A.; data curation: D.D.; writingoriginal draft preparation: L.L. and G.A.; writing-review and editing: all authors; supervision: L.L. All authors have read and agreed to the published version of the manuscript.

Funding: Funding was provided by IDECC and, indirectly, by the Mohamed Bin Zayed Species Conservation Fund and the Linnaeus Fund (to L.L.).

Institutional Review Board Statement: Not applicable.

Data Availability Statement: Data are not available in public repositories, and the data utilized in the paper are fully presented in the paper. 
Acknowledgments: We are indebted to E.A. Eniang, C. Ebin, G.C. Akani, and N. Amadi for various sources of help both in the field and in the logistics during the study period. We thank two anonymous referees for their very helpful comments on the submitted draft.

Conflicts of Interest: The authors declare no conflict of interest.

\section{References}

1. De Palma, M.; Di Gennaro, C. Description of Fornasinius hermes sp. nov.(Coleoptera: Cetoniidae: Goliathini). Entomol. Afr. 2017, 22, 31-38.

2. De Palma, M.; Takano, H.; Leonard, P.; Bouyer, T. Barcoding analysis and taxonomic revision of Goliathus Lamarck, 1802 (Scarabaeidae, Cetoniinae). Entomol. Afr. 2020, 25, 11-32.

3. Muafor, F.J.; LeGall, P. Beetle trade in South West Cameroon. IRD, Yaoundé. Available online: https://horizon.documentation. ird.fr/exl-doc/pleins_textes/divers13-11/010057004.pdf (accessed on 5 June 2021).

4. Muafor, F.J.; Levang, P.; Angwafo, T.E.; Gall, P.L. Making a living with forest insects: Beetles as an income source in Southwest Cameroon. Int. For. Rev. 2012, 14, 314-325. [CrossRef]

5. Le Gall, P. Affinités biogéographiques des Insectes du “Dahomey gap": Présence d'une population de Goliathus goliatus Linné, 1771, au Bénin (Coleoptera, Scarabaeidae, Cetoniinae). Bull. Soc. Entomol. Fr. 2010, 115, 17-21.

6. Chiari, S.; Zauli, A.; Mazziotta, A.; Luiselli, L.; Audisio, P.; Carpaneto, G.M. Surveying an endangered saproxylic beetle, Osmoderma eremita, in Mediterranean woodlands: A comparison between different capture methods. J. Insect Conserv. 2013, 17, 171-181. [CrossRef]

7. Bardiani, M.; Chiari, S.; Maurizi, E.; Tini, M.; Toni, I.; Zauli, A.; Audisio, P. Guidelines for the monitoring of Lucanus cervus. Nat. Conserv. 2017, 20, 37-78. [CrossRef]

8. Brygadyrenko, V.V.; Reshetniak, D.Y. Morphological variability among populations of Harpalus rufipes (Coleoptera, Carabidae): What is more important-The mean values or statistical peculiarities of distribution in the population? Folia Oecologica 2014, 41, 109-133.

9. Komlyk, V.O.; Brygadyrenko, V.V. Morphological variability of Bembidion aspericolle (Coleoptera, Carabidae) populations in conditions of anthropogenic impact. Biosyst. Divers. 2019, 27, 21-25. [CrossRef]

10. Zverev, V.; Kozlov, M.V.; Forsman, A.; Zvereva, E.L. Ambient temperatures differently influence colour morphs of the leaf beetle Chrysomela lapponica: Roles of thermal melanism and developmental plasticity. J. Therm. Biol. 2018, 74, 100-109. [CrossRef]

11. Komlyk, V.O.; Brygadyrenko, V.V. Morphological variability of Bembidion minimum (Coleoptera, Carabidae) populations under the influence of natural and anthropogenic factors. Biosyst. Divers. 2019, 27, 250-269. [CrossRef]

12. Kikuchi, D.W.; Waldron, S.J.; Valkonen, J.K.; Dobler, S.; Mappes, J. Biased predation could promote convergence yet maintain diversity within Müllerian mimicry rings of Oreina leaf beetles. J. Evol.Biol. 2020, 33, 887-898. [CrossRef] [PubMed]

13. Xie, D.; Yang, Z.; Liu, X.; Cui, S.; Zhou, H.; Fan, T. Broadband omnidirectional light reflection and radiative heat dissipation in white beetles Goliathus goliatus. Soft Matter. 2019, 15, 4294-4300. [CrossRef] [PubMed]

14. Godeau, G.; Godeau, R.P.; Orange, F.; Szczepanski, C.R.; Guittard, F.; Darmanin, T. Variation of Goliathus orientalis (Moser, 1909) elytra nanostructurations and their impact on wettability. Biomimetics 2018, 3, 6. [CrossRef] [PubMed]

15. Hinton, H.E.; Jarman, G.M. Physiological colour change in the elytra of the hercules beetle, Dynastes Hercules. J. InsectPhysiol. 1973, 19, 533-549. [CrossRef]

16. Huang, J.P. The Hercules beetles (subgenus Dynastes, genus Dynastes, dynastidae): A revisionary study based on the integration of molecular, morphological, ecological, and geographic analyses. Publ. Mus. Zool. Univ. Mich. 2017, 206, 1-31.

17. Verdyck, P.; de Wolf, H.; Backeljau, T.; Hulselmans, J. A genetic study of two colour forms of Phyllotreta cruciferae (Chrysomelidae: Alticinae). In Chrysomelidae Biology, Volume 1: The Classification, Phylogeny and Genetics; Jolivet, P.H.A., Cox, M.L., Eds.; SPB Academic Publishing: Amsterdam, The Netherlands, 1996; pp. 389-397.

18. IUCN. The IUCN Red List of Threatened Species. IUCN, Gland. 2021. Available online: www.iucnredlist.org (accessed on 3 August 2021). 